BJHS: Themes 1: 115-143, 2016. C British Society for the History of Science 2016. This is an Open Access article, distributed under the terms of the Creative Commons Attribution licence (http://creativecommons.org/licenses/by/4.0/), which permits unrestricted re-use, distribution, and reproduction in any medium, provided the original work is properly cited.

doi:10.1017/bjt.2016.4 First published online 22 March 2016

\title{
Another global history of science: making space for India and China
}

\author{
ASIF SIDDIQI*
}

\begin{abstract}
Drawing from recent theoretical insights on the circulation of knowledge, this article, grounded in real-world examples, illustrates the importance of 'the site' as an analytical heuristic for revealing processes, movements and connections illegible within either nation-centred histories or comparative national studies. By investigating place instead of project, the study reframes the birth of modern rocket developments in both China and India as fundamentally intertwined within common global networks of science. I investigate four seemingly disconnected sites in the US, India, China and Ukraine, each separated by politics but connected and embedded in conduits that enabled the flow of expertise during (and in some cases despite) the Cold War. By doing so, it is possible to reconstruct an exemplar of a kind of global history of science, some of which takes place in China, some in India, and some elsewhere, but all of it connected. There are no discrete beginnings or endings here, merely points of intervention to take stock of processes in action. Each site produces objects and knowledge that contribute to our understanding of the other sites, furthering the overall narrative on Chinese and Indian efforts to formalize a 'national' space programme. The focus on these four sites reveals a global network of science in motion, linked by the common goals of building powerful rockets to explore space.
\end{abstract}

In revisiting the Cold War origins of China and India's efforts to create the infrastructure to launch missiles and satellites into space, we find twin projects, driven and defined by domestic aspirations that were couched in the analogous language of science and modernization. This link between nation, science and modernization was not particularly unique to China and India but it held special resonance for political and scientific elites who linked the possibility of the modern future with the historical valence of past civilizational greatness, available for recovery in each case. ${ }^{1}$ Yet, at the material level, at least as we have normally understood these stories, these were fundamentally independent projects, not surprising given the strained nature of Chinese-Indian relations, especially after the Sino-Indian war in 1962. One manifestation of these nation-centred

* Dealy 624, Department of History, 441 E Fordham Road, Fordham University, Bronx, NY 10458, USA. Email:siddiqi@fordham.edu.

1 Note the frequent invocation of the 'invention' of rockets in China as early as the tenth century, and likewise the references to astronomy as practised in ancient India. See 'Rockets of ancient China', at www. chinaculture.org/gb/en_madeinchina/2005-07/21/content_70826.htm; M.R. Ananthasayam, 'A relook [sic] into the historical progress and philosophy of Indian space exploration', paper presented at the 58th International Astronautical Congress, Hyderabad, India, 24-28 September 2007. 
stories is the vast number (as well as ambit) of studies on the histories of national (space, missile etc.) programmes such as the 'Chinese rocket programme' or the 'Indian space programme'.2 Their narratives operate without imbrication, without flow of knowledge, matériel or people between them. I am not quibbling with this basic formulation but, in this essay, suggest that there are alternative approaches to seeing this gestational period in the two countries that may render visible occluded networks, contacts and flows, that cut across geographical and temporal lines.

The central animating conceit of the current study on Indian and Chinese space efforts is to investigate place instead of project. By doing so I hope to reframe the birth of modern rocket developments in both China and India as fundamentally intertwined within common global networks of science. ${ }^{3}$ By looking at four seemingly disconnected sites, each separated by politics but connected and embedded in conduits that enabled the flow of expertise during (and in some cases despite) the Cold War, but with a shared common goal - departure from the Earth - it is possible to reconstruct an exemplar of a kind of global history of science, some of which takes place in China, some in India, and some elsewhere, but all of it connected. There are no discrete beginnings or endings here, merely points of intervention to take stock of processes in action. Each site produces objects and knowledge that contribute to our understanding of the other sites, furthering the overall narrative on Chinese and Indian efforts to formalize a 'national' space programme. As will become evident in the main narrative, because of the emphasis on place over project, we loosen our attachment to the most basic glue that holds history together - chronology.

The study is positioned in relation to two bodies of literature. The first is the expanding corpus of scholarship on what might loosely be called a 'global history' of science and technology. There is an abundance of work worthy of consideration here, some of it generated by scholars of colonial science who, in the 1990s, sought to avoid the kind of unidirectional centre-periphery diffusionary models redolent of much of the early work in the field. As a result, historians of science - some influenced by post-colonial studies have rejected arbitrary signifiers such as 'indigenous' and 'Western' in describing the objects of their study in favour of 'more interactive, culturally nuanced, multi-sited debate' over the history of science and technology. ${ }^{4}$ Second, my essay is an intervention

2 There are now quite a large number of English-language journalistic accounts of both the Chinese and Indian space programmes. See Brian Harvey, China's Space Program: From Conception to Manned Spaceflight, Chichester: Springer-Praxis, 2004; Harvey, China in Space: The Great Leap Forward, Chichester: Springer-Praxis, 2013; Roger Handberg and Zhen Li, Chinese Space Policy: A Study in Domestic and International Politics, Abingdon: Routledge, 2007; Gregory Kulacki and Jeffrey G. Lewis, A Place for One's Mat: China's Space Program, 1956-2003, Cambridge, MA: American Academy of Arts \& Sciences, 2008; Gopal Raj, Reach for the Stars: The Evolution of India's Rocket Programme, New Delhi: Viking, 2000; P.V. Manoranjan Rao and P. Radhakrishnan, A Brief History of Rocketry in ISRO, Hyderabad: Universities Press, 2012.

3 See also my initial thoughts on this problematic: Asif Siddiqi, 'Competing technologies, national(ist) narratives, and universal claims: towards a global history of space exploration', Technology and Culture (2010) 51, pp. 425-443.

4 For a summary and critique of the recent literature in colonial and postcolonial science in the global context see David Arnold, 'Europe, technology, and colonialism in the 20th century', History and Technology (2005) 21, pp. 85-106. See also the special issue on Science and Global History, 1750-1850: Local Encounters and Global 
into the smaller but growing literature on what might reductively be called 'nation-in-the-world' scholarship - as in recent works that take on national scientific projects but in an official context, enabled through international agreements. ${ }^{5}$ It is within this problematic that John Krige cautions that we cannot and should not forget the nation as an essential category of understanding, despite all the multivalent and rich transnational processes in the practice of science in the late twentieth century. ${ }^{6}$ There has been quite a bit of this work in the context of India and China, and I benefit from key insights drawn from this scholarship, including claims that while science and national development were firmly coupled, both rhetorically and in practice in the post-Second World War era, historians have to confront 'messy' phenomena that do not fit into the classic genealogy of science and international relations as mutually constitutive, working along clean interfaces between nations. ${ }^{7}$

This paper draws from insights from all of these literatures but also from more popular writers such as the urban studies journalist Mike Davis, whose Planet of Slums articulates a provocative heuristic approach to framing knowledge about the spatial politics of the globe unmoored from nation. ${ }^{8}$ I also take to heart Stacy Pigg's challenge that 'we now need to find out more about science and technology travel, not whether they belong to one culture or another' ${ }^{9}$ In the case of space research, such an approach, with a focus on how things travel through particular places, subverts the obvious sequence of space development in China and India in favour of non-linear connections that privilege flows in often counterintuitive ways. Here there is no 'Indian space programme' or 'Chinese rocket programme' but a series of moments grounded in sites that witnessed the transnational exchange of knowledge, matériel and people. Such a narrative has the possibility to render visible (in the words of Zuoyue Wang) the 'hidden transnational movements of people and instruments in science and technology'. ${ }^{10}$

Circulation in Itinerario (March 2009) 33, especially the piece by Lissa Roberts ('Situating science in global history'); Fa-ti Fan, 'The global turn in the history of science', East Asian Science, Technology and Society: An International Journal (2012) 6, pp. 249-258; Kapil Raj, 'Beyond postcolonialism ... and postpositivism: circulation and the global history of science', Isis (2013) 104, pp. 337-347; and the special issue on Transnational History of Science in the BJHS (2012) 45, especially the introduction (pp. 319-336) by Simone Turchetti, Nestor Herran and Soraya Boudia ('Introduction: have we ever been "transnational"? Towards a history of science across and beyond borders').

5 For a historiographic survey of the problematic of the 'nation' in the history of science see Mark Walker, 'The "national” in international and transnational science', BJHS (2012) 45, pp. 359-376.

6 John Krige, 'Embedding the national in the global: US-French relationships in space science and rocketry in the 1960s', in Naomi Oreskes and John Krige (eds.), Science and Technology in the Global Cold War, Cambridge, MA: MIT Press, 2014, pp. 227-250.

7 See, for example, the essays in Gabrielle Hecht (ed.), Entangled Geographies: Empire and Technopolitics in the Global Cold War, Cambridge, MA: MIT Press, 2011; Oreskes and Krige, op. cit. (6).

8 Mike Davis, Planet of Slums, London: Verso, 2006.

9 Warwick Anderson uses this quote in his 'Introduction: postcolonial technoscience', Social Studies of Science (2002) 32, pp. 643-658, 644. See also Stacy Pigg, 'Inventing social categories through place: social representations and development in Nepal', Comparative Studies in Society and History (1992) 34, pp. 491-513.

10 Zuoyue Wang, 'Transnational science during the Cold War', Isis (2010) 101, pp. 367-377, 368. 
The four sites I study here are Thumba (in the south Indian state of Kerala); Cambridge, Massachusetts; Beijing; and Dnepropetrovsk (formerly in the Soviet Union, now in Ukraine). I begin, somewhat arbitrarily at Thumba, where in the 1960s the architects of the Indian space programme established an international nexus for scientific and technical exchange enabled to a large degree by key Indian technocrats trained at MIT and other elite American institutions. Indian space officials also situated MIT in their orbit by recruiting its resources for initial satellite studies, especially a key project in 1970 that laid the foundation for future satellite work in India. MIT was, of course, the most important educational institution for a large number of diaspora Chinese scholars in the 1930s and 1940s, many of whom did their graduate work while Indians were there. Most of these Chinese scholars returned to Beijing to found the Chinese missile programme in the early 1950s. They set up institutions that were hybrids of the American model (which they were familiar with) and the Soviet model (enabled by massive cooperation in the 1950s). Soviet help - in the form of visiting advisers and actual rockets delivered - was indispensable for setting up initial production runs of the very first Chinese rockets in Beijing the late 1950s. Many of the visiting Soviet engineers, as well as the rocket hardware, came from the Ukrainian industrial city of Dnepropetrovsk, a site where Stalin had established the largest missile factory in the world. Here at Dnepropetrovsk, nearly fifteen years later, in the early 1970s, Soviet engineers worked with Indian scientists and engineers, many of whom had worked at Thumba in the past, to jointly develop the first Indian satellite, Aryabhata, launched by a Soviet rocket in 1975 .

\section{Beginning a space programme in India}

The basic narrative of the early days of India's space programme has been repeated in many places. It begins with the launch of a modest 'sounding' rocket from a launch site near the fishing village of Thumba at the southern tip of India in the waning months of 1963. Such rockets were designed to simply brush up against the upper atmosphere and use rudimentary scientific instruments to measure data of interest to scientists. There is a certain linearity about the received story, where a group of resourceful engineers, scientists and designers under the tutelage of the industrialist, scientist and institution builder Vikram Sarabhai gained valuable experience working with foreign rocket technology, most of it available at Thumba through bilateral agreements, initially with the United States, France and the Soviet Union, and then later with Great Britain, Japan and West Germany. In 1969, Sarabhai engineered the creation of the Indian Space Research Organisation (ISRO), which he headed while simultaneously heading its much higher-profile umbrella institution, the Department of Atomic Energy. His team, which cut its teeth training with foreign rockets, eventually began to build their own, some under license. With the blessing of then Prime Minister Indira Gandhi, Sarabhai tabled a ten-year plan for space research in 1970, which was enthusiastically followed by his successors after his untimely death in 1971 . Under the tutelage of Satish Dhawan, the Indians launched their first wholly home-made satellite 
successfully into orbit in 1980, a remarkable achievement that only a half a dozen countries had hitherto achieved. ${ }^{11}$ Looming over this narrative is the subtle shift from working with other countries to what almost all actors in the space programme (including Sarabhai) called 'indigenous' capability. There is no singular moment where we can observe a threshold from the former phenomenon to the latter, partly because through most of its early history, even through the satellite launch in 1980, Indian work on rocketry and space has been deeply connected to and embedded in global technoscientific networks. This is evident in the early launches from Thumba in the 1960s when it was unremarkable to have Indian technicians launch an American rocket with French experiment using Soviet ground equipment. All of these relationships were dynamic, contingent and possessed of their own peculiarities, but, as has become evident, at least until the early 1970s the most important relationship was one with the United States, particularly with NASA. ${ }^{12}$

The intimate connection between NASA and the burgeoning Indian space programme requires a deeper understanding of Sarabhai, his background and his leveraging of connections to build a space programme at home. Sarabhai, like his older colleague and patron, Homi Bhabha, grew up a child of wealth in a prominent family. And like Bhabha, Sarabhai was considered something of a prodigy; his elite and cultured sensibilities led him to a wide range of social and cultural interests and eventually to a $\mathrm{PhD}$ at Cambridge, interrupted briefly by the Second World War. His dissertation, entitled 'Cosmic ray investigations in tropical latitudes', brought together his two biggest passions, India and physics. During the Second World War, the two men had become colleagues and then friends at the Indian Institute of Science in Bangalore. They kept in touch through India's independence as Bhabha, now working closely with India's first prime minister, Jawaharlal Nehru, took on the leading role in independent India's efforts to establish advanced scientific infrastructure and expertise. In 1945 he formed the Tata Institute of Fundamental Research (TIFR) in Bombay, and three years later he was appointed to head India's Atomic Energy Commission. ${ }^{13}$ Sarabhai, meanwhile, used his family resources to establish another research institution, the Physical Research Laboratory (PRL), located in his family home of Ahmedabad, which specialized in Sarabhai's field of research, cosmic ray physics. ${ }^{14}$ Here, the focus was less on theoretical physics than on experimental work. The laboratory grew slowly but gained strength by the late 1950s, with equipment imported from abroad providing young students with

11 This narrative is closely followed by a number of useful journalistic texts on the Indian space programme. See particularly Raj, op. cit. (2); Rao and Radhakrishnan, op. cit. (2).

12 This is the largely the focus of Ashok Maharaj, "Space for "development": US-Indian space relations, 1955-1976', PhD dissertation, Georgia Institute of Technology, 2011. See also Maharaj, 'An overview of NASA-India relations', in John Krige et al., NASA in the World: Fifty Years of International Collaboration in Space, London: Palgrave Macmillan, 2013, pp. 211-234.

13 Jahnavi Phalkey, Atomic State: Big Science in Twentieth-Century India, Delhi: Permanent Black, 2013; Robert S. Anderson, Nucleus and Nation: Scientists, International Networks, and Power in India, Chicago: The University of Chicago Press, 2010.

14 For Sarabhai see Padmanabh Joshi (ed.), Vikram Sarabhai: The Man and the Vision, Ahmedabad: Mapin Publishers, 1992. For a recent thoughtful examination of his life see Amrita Shah, Vikram Sarabhai: A Life, New Delhi: Penguin, 2007. 
opportunities for new and exciting research. In the 1950s, both Bhabha and Sarabhai were instrumental in creating a network of institutions across the Indian landscape, the former in the scientific and applied-research sector and the latter in Indian textiles and chemical industries. ${ }^{15}$ Bhabha, especially, and Sarabhai by the late 1950 s were embedded in and acted through international scientific networks that exposed them to a large range of influential scientists and administrators, mainly in Europe and the US, while also bestowing on them the authority of international scientific organizations when acting within and outside on behalf of India. Besides brokering numerous agreements with France, Great Britain and Canada to help establish a burgeoning activity in the civilian use of nuclear energy, Bhabha, as chair of the Indian government's Atomic Energy Commission, also was keenly visible at international conferences. ${ }^{16}$

Both Bhabha and Sarabhai represented an ethos that was not uncommon among certain technocratic elites who crossed the divide between the colonial and the postcolonial in that their interests were firmly shaped by the possibilities of modern science and technology, especially as it was manifested in nation states more economically developed than India - the countries of Western Europe, the United States, and the Soviet Union. Although some of their contemporaries employed a more critical approach to the adoption of Western science and technology through the cultivation of domestic private industry, Bhabha and Sarabhai combined their obvious nation-building initiatives with a passionate belief in the power of science and technology to act as transformative instruments of social relations. In the context of development, they were particularly captivated by the work of Western social scientists such as MIT professor Walt Rostow, the author of the (in)famous The Stages of Economic Growth: A Non-communist Manifesto, issued in 1960, just at the cusp of the formation of the Indian rocket project. Rostow's work on the linearity of economic development - particularly its positivist ethos - was deeply influential for decades as modernization theory extended its grip on international philanthropic and economic institutions, many of which, such as the Ford and Rockefeller Foundations, had firm links with the South Asian elite. ${ }^{17}$ Bhabha and Sarabhai's writings of the period betray many of the predilections of modernization theorists. Sarabhai's meditations on development in India, for example, were almost always couched in terms of stages of growth; and one of his favourite phrases was for India to 'leapfrog' ahead to achieve developmental parity with the First World,

15 Anderson, op. cit. (13).

16 For Bhabha see Indira Chowdhury and Ananya Dasgupta, A Masterful Spirit: Homi J. Bhabha, 19091966, Delhi: Penguin Books, 2010; Chintamani Deshmukh, Homi Jehangir Bhabha, New Delhi: National Book Trust, 2003; G. Venkataraman, Bhabha and His Magnificent Obsessions, Hyderabad: Universities Press, 1994.

17 Michael E. Latham, Modernization as Ideology: American Social Science and 'Nation Building' in the Kennedy Era, Chapel Hill: University of North Carolina Press, 2000; Nils Gilman, Mandarins of the Future: Modernization Theory in Cold War America, Baltimore: Johns Hopkins University Press, 2004; David C. Engerman, 'West meets East: the Center for International Studies and Indian economic development', in David C. Engerman, Nils Gilman, Mark H. Haefele and Michael E. Latham (eds.), Staging Growth: Modernization, Development, and the Global Cold War, Amherst: University of Massachusetts Press, 2003, pp. 199-223; Nicole Sackley, 'Passage to modernity: American social scientists, India, and the pursuit of development, 1945-1961', PhD dissertation, Princeton University, 2004. 
something he believed an Indian space programme would facilitate. They also accepted without question the portability of technology. Bhabha noted late in his life that 'what the developed countries have and the underdeveloped lack is modern science and an economy based on modern technology'. ${ }^{18}$ Sarabhai used the same kind of thinking in the first major statement on the future of the Indian space programme, a manifesto for the next ten years issued in 1970. He noted that 'there is a totality about the process of development which involves not only advanced technology and hardware but imaginative planning of supply and consumption centres, of social organization and management, to leapfrog from a state of backwardness and poverty'. ${ }^{19}$ A space programme, in other words, was a tool for economic development and nation building.

\section{Thumba}

India's seedling activities relating to space began with the International Geophysical Year (IGY) of 1957-1958, which provided Indian scientists with their first practical manifestation of the advantages of India's geography for space research. India's tropical location, particularly the fact that its southern tip passes through the magnetic equator (as opposed to the geographical equator) made it a location attractive for those studying high-energy cosmic rays (since low-energy particles were screened off by the Earth's magnetic field). A joint project with the Smithsonian Institution to establish a satellite observation facility in Nainital (now in Uttarakhand) in northern India spurred Vikram Sarabhai to more ambitious ends. ${ }^{20}$ There is no reason to doubt Sarabhai's stated vision of creating a programme devoted to the welfare of the Indian population, but his strategy for building this project depended on a number of extremely pragmatic measures. The first was to create a powerful institutional home with links to the top levers of Indian politics and industry. With Bhabha's sponsorship, in August 1961, Sarabhai moved his Physical Research Laboratory under the umbrella of Bhabha's Department of Atomic Energy. Hardly mentioned in the standard histories of Indian space activities, this integration of space with nuclear matters was an important strategic move, for the institutional and symbolic alignment between the two proved beneficial to both: on the one hand, the space programme (Sarabhai) could invoke the authority of the atomic programme; and on the other hand, the atomic programme (Bhabha) could use the space programme to create a patina of peaceful scientific work, useful to shield it from the frequent suspicions of Westerners who believed otherwise. Soon, in February 1962, partly driven by the need to have a single focal point for dealing with international partners, Sarabhai engineered the formation of the Indian National Committee for Space

18 H.J. Bhabha, 'Science and the problems of development', Science (4 February 1966) 151, pp. 541-548, 541.

19 Atomic Energy Commission, Government of India, Atomic Energy and Space Research: A Profile for the Decade 1970-80, Delhi: Atomic Energy Commission, 1970, pp. iv-v

20 Teasel Muir-Harmony, 'Tracking diplomacy: the International Geophysical Year and American scientific and technical exchange with East Asia', in Roger D. Launius, James Rodger Fleming and David H. DeVorkin (eds.), Globalizing Polar Science: Reconsidering the International Geophysical Years, New York: Palgrave Macmillan, 2010, pp. 279-305. 
Research (INCOSPAR), which at this point was essentially a small cell within his old Physical Research Laboratory. ${ }^{21}$

The second important strategy for Sarabhai was to define INCOSPAR's mission such that it leveraged India's geographical advantages for the study of cosmic rays. Sarabhai's genius was to invoke and publicize the value of this research in order to involve the international scientific community and, more to the point, to recruit Western nations who already had the capability to lift payloads up into space to come to Thumba with all their equipment in tow. Western participation in a scientific rocket programme to investigate phenomena in the magnetic equator served three important functions: it gave INCOSPAR's activities the cloak of legitimacy as a worthwhile project, it provided India with a large amount of technological infrastructure free of charge, and it insulated criticism of the space programme from a domestic audience who might otherwise wonder why India was spending money on space exploration when it had more pressing problems on the ground. ${ }^{22}$

In the early 1960 s, only two nations had the capacity to launch objects into orbit, the United States and the Soviet Union, and Sarabhai visited each in 1961 and 1962 respectively to inquire about cooperation. ${ }^{23}$ At the time, the Soviet Union, and particularly the Soviet space programme, were deeply secretive, covered in layer upon layer of obfuscation. Built entirely on the edifice of their strategic missile weapons programme, the Soviets maintained the fiction of a peaceful programme by revealing almost nothing about the inner workings of their cosmic efforts. ${ }^{24}$ One outcome of that policy was hardly any cooperation between the Soviet Union and other nations, at least in the early 1960s. Sarabhai's efforts were thus not rewarded. NASA was a different case, its international overtures shaped by broader political ends sculpted at the highest levels of the executive branch. ${ }^{25}$ By the early 1960s the agency had initiated a number of programmes with nations such as Great Britain, Canada, Italy and Japan. Inspired by this activity, in May 1961 Sarabhai arrived in Washington, DC to meet with NASA representatives. He came armed with two ideas: to create a sounding rocket programme based in India but using American rockets, and to have NASA help the Indians set up a satellite tracking and telemetry station on Indian soil. ${ }^{26}$

21 The cabinet approved the decision on 10 February, but the public announcement, by the Department of Atomic Energy, was made 16 February 1962. Amembassy New Delhi to State Department, 2 March 1962, National Archives and Records Administration (NARA) II, RG 59, Central Decimal File, 1960-1963, Box 3112, Folder 991:801/3-861.

22 I provide a detailed history of INCOSPAR's formation in Asif A. Siddiqi, 'Science, geography, and nation: the global creation of Thumba', History and Technology, forthcoming.

23 Sarabhai visited Moscow to explore the possibility of cooperation in space activities in September 1962. See 'Indian space scientist', TASS English, Moscow, 3 September 1962, 1940 GMT; and 9 September 1962, 1100 GMT.

24 For secrecy and the Soviet space programme see Asif A. Siddiqi, 'Cosmic contradictions: popular enthusiasm and secrecy in the Soviet space program', in James T. Andrews and Asif A. Siddiqi (eds.), Into the Cosmos: Space Exploration and Soviet Culture, Pittsburgh: University of Pittsburgh Press, 2012 , pp. 47-76.

25 John Krige, 'Introduction and historical overview: NASA's international relations in space', in Krige et al., op. cit. (12), pp. 3-21.

26 Memorandum of conversation - on May 18, 1961, 1 June 1961, NARA II, RG 59, Office of the Secretary, Special Asst. to Sec. of State for Atomic Energy Matters, 1948-1962, General Records Relating to Atomic Energy Matters, 1948-1962, Box 333, Folder 14A-Cooperative Space Programs 9. India, 1961-62. 
If NASA was an instrument of a larger agenda, Sarabhai himself seized an opportunity to frame the cooperation in terms that were beneficial to Indian aspirations and to him personally. This is evident in the correspondence with NASA in the following months as NASA began preparations to implement the more modest of Sarabhai's proposals, the satellite data acquisition facility. In a letter dated 19 June outlining the basic idea for such a facility, Sarabhai proposed that it be housed in Ahmedabad, at the institution he founded and continued to oversee, the Physical Research Laboratory (PRL).

In structuring the satellite ground station agreement with NASA, Sarabhai drew input from an international network of scientists centred at MIT, where Sarabhai had secured for himself an appointment at the Laboratory for Nuclear Science under Bruno Rossi, the renowned Italian experimental physicist and one of the founders of X-ray astronomy. Every summer, as a 'senior visiting scientist', Sarabhai would spend a few weeks at Cambridge, extending his cosmic ray research work, which he coordinated with activity back at his PRL in Ahmedabad. With the assent of Rossi at MIT, Sarabhai articulated a rationale that NASA would find attractive in building a station in India: it would help collect data from a satellite belonging to NASA, Explorer XI, whose orbital track was so shaped that there were gaps in collecting information from its scientific instruments, particularly as it flew over South Asia. ${ }^{27}$ The scientific instrument on the satellite, a gamma ray telescope, was developed at MIT under William L. Kraushaar, who, as it turned out, worked in Rossi's group, which included Sarabhai. Here, Sarabhai's genius was to propose to NASA something that would be difficult, if not impossible, to reject, while establishing a bedrock for the future Indian space programme. With mutually beneficial goals formulated, the project moved quite fast. NASA and Indian representatives were able to establish the telemetry data reception station at Ahmedabad by the end of 1961, less than a year after Sarabhai had brought up the idea. Nearly $\$ 93,000$ of equipment 'on loan' from NASA was delivered to Sarabhai's laboratory with four Americans dispatched to help set everything up. ${ }^{28}$ Once activated, the facility was operated solely by Indian personnel for many years. Both parties saw the project as an unqualified success, and in May 1962 Nehru himself visited the tracking station.

Subsequently, in October 1962, INCOSPAR signed an agreement with NASA to launch American sounding rockets from Indian soil to investigate upper atmospheric phenomena. This arrangement perfectly dovetailed with Sarabhai's strategy to involve Western nations in using India's landmass as a launching pad for space experimentation. According to the deal, NASA would conduct two experiments jointly with the Indians, one to release sodium vapour at high altitudes to measure upper atmospheric winds and the other to study the 'equatorial electrojet', a current system found directly above the magnetic equator. As part of the programme, NASA would donate thirteen rockets, while the Indians would furnish some of the scientific experimentation. NASA would also provide a whole host of equipment, all of which (besides the rockets) was on

27 Explorer XI, the world's first gamma-ray astronomy satellite, was launched into orbit on 27 April 1961.

28 'Telemetry station for Ahmedabad, India', 6 September 1961, NARA II, RG 59, Office of the Secretary, Special Asst. to Sec. of State for Atomic Energy Matters, 1948-1962, General Records Relating to Atomic Energy Matters, 1948-1962, Box 333, Folder 14A - Cooperative Space Program 9. India, 1961-62. The estimated total cost was $\$ 92,718$ plus $\$ 10,000$ for shipping. 
loan. The agreement emphasized that '[n]o exchange of funds is provided for and all scientific results of the experiments will be made freely available to the world scientific community'. ${ }^{29}$

By the time NASA agreed to this arrangement, an INCOSPAR scientist from Sarabhai's PRL, E.V. Chitnis, with the help of colleagues from NASA who had flown in from the United States, found an appropriate place for these launches at Thumba, a village close to the Kerala capital of Trivandrum in south India close to the magnetic equator. ${ }^{30}$ Using the vacated premises of a church, INCOSPAR employees set up the skeletal infrastructure to support these launches. Sarabhai also obtained equipment from the French, enabled through a friendship with Jacques Blamont, a French scientist who provided a sodium vapour experiment that he had tested in French colonial Algeria, where the French had had a modest rocket launch programme since the late 1950s.

The culmination of all this activity was the very first launch, from Thumba, on 21 November 1963 of an American Nike-Apache rocket. In concert with two Americans and two French technicians, the Indians - almost all of them protégés of Sarabhai from their research infrastructure - successfully launched the sodium experiment about 170 kilometres up into the very upper reaches of the atmosphere, the vapour spreading a bright orange cloud trail that was visible to many from the ground. ${ }^{31}$ This event has since assumed an iconic status in the literature - all official histories date it as the birth of the Indian space programme, partly because the infrastructure created at Thumba, resulting in the convergence of equipment from the Americans and the French, and later the Soviets, helped create the necessary expertise for the future Indian space programme. It was near Thumba that in the 1970s the newly created Indian Space Research Organisation formed the Vikram Sarabhai Space Centre, now the largest facility in the Indian space programme, where massive satellite launch vehicles are designed and manufactured before being delivered to the eastern coast of India at Sriharikota for launch into orbit. The agreements forged by Sarabhai and his successor, Satish Dhawan, allowed Thumba to become a fundamentally unique site in Cold War science, where representatives of the two rival superpowers could commingle and work with a common purpose, relatively insulated from the theatrical bluff and bluster of their respective national leaders. For the hosts, Thumba possessed an entirely different import: it was an important training ground for a generation of Indians, a site where technology could exchange hands without concern, providing Indians with an extraordinary window into contemporary rocket technology.

29 Memorandum of Understanding between the Department of Atomic Energy and the United States National Aeronautics and Space Administration, 11 October 1962, NARA II, RG 59, Bureau of International Scientific and Technological Affairs, Central Files, 1964-1966, Box 1, Folder Space \& Astronautics SP 1 Gen. Policy. Plans. Coordination, 1964.

30 For the long and torturous history of the 'creation' of Thumba see Siddiqi, op. cit. (22).

31 'First rocket launched at Thumba International Range', NASA News Release 63-105, 22 November 1963, NASA History Division, Historical Reference Collection, International Programs, India-U.S. Folder. For many vivid recollections of the day see 20 Years of Rocketry in Thumba, 1963-1983, Trivandrum: Central Documentation Division, Vikram Sarabhai Space Centre, 1983, pp. 71-83. 
Indians working at Thumba, the 'foundational' engineers of the Indian space programme, were a varied lot, but many of them - especially the senior scientists and engineers - shared one rite of passage: they had done their graduate work in American (and, to a lesser degree, British) institutions of higher education. ${ }^{32}$ More strikingly, the number and prominence of alumni from MIT was noteworthy, and included E.V. Chitnis, who played an important role in selecting the geographical site for Thumba and worked with Bruno Rossi's Cosmic Ray Group at MIT from 1958 to 1961; Yash Pal, who received his $\mathrm{PhD}$ in physics in 1958 from MIT, and who later became director of the Space Applications Center at the Indian Space Research Organisation; and Brahm Prakash, who completed his ScD in 1949 at MIT, and later headed the rocket vehicle development centre of ISRO. ${ }^{33}$ Of course, the most important connection with MIT was through Vikram Sarabhai, who had a formal appointment with MIT throughout the 1960s as a senior visiting scientist in the Physics Department. MIT, and Cambridge, Massachusetts writ large, were also the hub of the most influential group of modernization theorists identified with Walt Rostow, who knew Sarabhai well. Much more than simply a common reference point for many of the actors in the Indian space programme, MIT was a key node in the global scientific network that enabled the burgeoning space activities of a number of different countries, including both India and China.

\section{MIT: India and China}

For much of the twentieth century, one option for higher education for young men from elite Indian families was to go abroad, usually to Great Britain or the United States. MIT was probably the most obvious destination for many, especially those aspiring to a degree in the applied sciences, engineering or economics, partly because of the precedent set by a number of influential and vocal Indian alumni of MIT who advocated on its behalf. The nearly one hundred Indians who were granted doctoral degrees in the colonial period - almost all of whom returned home - brought back with them a diverse set of experiences that informed their activities in India. Ross Bassett notes that in the first forty years of independence,

MIT graduates occupied an astounding number of the highest-level positions in the Indian technical community - more than graduates of any other single school in the United States or the United Kingdom, and quite possibly more than the graduates of any single school in India. ${ }^{34}$

This tradition of Indian elites going to the top schools in the US continued past 1947, complemented now by efforts to replicate the MIT model in India through the founding of several new institutions, including campuses of the Indian Institute of Technology (IIT), particularly the one at Kanpur, and the Birla Institute of Technology and

32 See the list of senior engineers of INCOSPAR (and later the Indian Space Research Organisation, ISRO) in Maharaj, 'Space for “development”', op. cit. (12), p. 208.

33 A chapter in Yash Pal's biography gives a flavour of Indian networks in and around MIT. See Biman Basu, Yash Pal: A Life in Science, Noida: Vigyan Prasar, 2006, pp. 31-44.

34 Ross Bassett, 'MIT-trained swadeshis: MIT and Indian nationalism, 1880-1947', Osiris (2009) 24, pp. 212-230, 229-230. 
Science. ${ }^{35}$ The IIT system, as well as Birla, served as a major training node for dozens of Indian engineers and specialists who later went on to work for ISRO in the 1970s and 1980s.

MIT was not simply a passive institution in the web of activities that energized the Indian space programme; it also actively enabled it, in unusual and unexpected ways. In the mid-1960s, as the door opened for US-Indian cooperation in space, MIT administrators actively sought to expand it, framing such cooperation as complementing Cold War strategies to contain both China and the spread of nuclear weapons. In the aftermath of China's successful demonstration of nuclear capability in October 1964, many in the administration of Lyndon B. Johnson feared a possible symmetric response from India. In anticipation of MIT dean of the School of Science Jerome Wiesner's visit to Delhi in January 1965, the State Department explicitly agreed with Wiesner's 'strong' feeling

that in order to divert the Indians from the path of making a bomb, they should be encouraged to take the major lead in moving towards non-proliferation. He felt that this [space activity] was the only realistic substitute for diverting their attention from achieving a nuclear weapons capacity. ${ }^{36}$

As part of accelerating this cooperation, both James Webb, the NASA chief, and Sarabhai, representing INCOSPAR, independently came upon the idea of using an American direct-broadcasting satellite to beam educational programmes to the poor in India. ${ }^{37}$

Sarabhai frequently spoke and wrote of the emancipatory powers of satellite technology to beam educational programmes to India's poor, a project he called INSAT. The idea of using modern media technology for development was not new; its principal advocate was Daniel Lerner, the social scientist at MIT who specialized in the role of communications in development, and who is best remembered for his monograph The Passing of Traditional Society, which shaped Cold War-era ideas about the use of mass media to promote social and economic progress in newly independent nations. ${ }^{38}$ Undoubtedly influenced by Lerner's work, Sarabhai pushed the idea of INSAT as a key node in the work of the Indian space programme in the 1970s. Lerner, in turn, praised Sarabhai's project as a 'brilliant example of leapfrogging', adding, 'Given the problems raised by India's acceleration of history and its instant mobilization of the

35 Stuart Leslie and Robert Kargon, 'Exporting MIT: science, technology, and nation-building in India and Iran', Osiris (2006) 21, pp. 110-130; Kim Patrick Sebaly, 'The assistance of four nations in the establishment of the Indian Institutes of Technology, 1945-1970', PhD dissertation, University of Michigan, 1972.

36 'Proposed Wiesner visit to New Delhi', 31 December 1964, NARA II, RG 59, Bureau of International Scientific and Technological Affairs, Central Files, 1964-1966, IANEC 1962-1963 to Relationships - N A S 1962-65, Box 6, Folder Relationships - NASA 1962-65.

37 The first discussion at the State Department level took place on 19 May 1966. See 'Proposal for an experimental satellite project involving direct broadcast of educational TV programs for India', 15 October 1966, NARA II, RG 59, Bureau of International Scientific and Technological Affairs, Miscellaneous Files, 1961-66, A.E. Pardee-Memos to Hornig's Visit to Pakistan, Box 2, Folder Visits of Sarabhai (10/12-27/66) and Sethna (10/3-20/66).

38 Daniel Lerner, The Passing of Traditional Society: Modernizing the Middle East, New York: Free Press, 1958. 
periphery, this type of leapfrogging over the long western experience is what India needs most'. 39

Building on some initial exploratory studies done with both NASA and US industry, Sarabhai reached out to MIT - in specific, its associated Lincoln Laboratories - to assist in conceptualizing INSAT. ${ }^{40}$ Lincoln Lab had been established in 1951 on the outskirts of Boston to institutionally support research and development on the nation's air defence system. By the late 1960s, it had become one of the central nodes in MIT's connections with the Department of Defense, a place where the bulk of MIT's classified research on weapons occurred. ${ }^{41}$ Sarabhai's interest was piqued by the fact that Lincoln Lab had developed devices and techniques for satellite communications for the US Air Force. ${ }^{42}$ Because Lincoln Lab's funding came directly from the Department of Defense - although it was formally associated with MIT - Sarabhai reached out to the Pentagon in the autumn of 1969. In October, Sarabhai wrote to US Secretary of the Air Force Robert Seamans to inquire about the possibility of Lincoln Lab initiating a joint study with Indian scientists and engineers on a communications satellite. Seamans was quick to respond to Sarabhai, sending off a short note that he (Seamans) had spoken to MIT provost Jerome Wiesner about Sarabhai's proposal. He added that he had 'every hope that it will be possible to help you in this fashion'. ${ }^{43}$

Once Seamans enabled the arrangement, there remained two major hurdles: to determine the scope of the project and to determine a source of funding. With respect to the latter, Sarabhai clearly had in mind a project to design a satellite whose first production model would be made in the United States, with follow-on models made in India. For funding, he believed that either USAID or the Ford Foundation would come through. ${ }^{44}$ Wiesner came to Sarabhai's help and solicited the Ford Foundation to provide funds, which they did, an amount of nearly $\$ 66,000$ for the first part of the study to be carried out at Lincoln Lab. ${ }^{45}$ The study was led by F. William Sarles Jr, a well-known communications satellite expert at MIT who had worked on a military communications satellite project in the 1960s; the Indian team (of six men) was led by Pramod Kale, one of Sarabhai's key deputies. The MIT-based INSAT study was

39 Daniel Lerner and Lyle M. Nelson, eds., Communication Research: A Half-Century Appraisal, Hawaii, East West Centre, 1977, p. 162.

40 This section of the paper is summarized from Asif Siddiqi, 'Making space for the nation: satellite television, Indian scientific elites, and the Cold War', Comparative Studies in South Asia, Africa, and the Middle East (2015) 35, pp. 35-49.

41 For official institutional histories see Alan A. Gromestein (ed.), MIT Lincoln Laboratory: Technology in Support of National Security, 1951-2011, Lexington, MA: MIT Lincoln Laboratory, 2011; Eva C. Freeman (ed.), MIT Lincoln Laboratory: Technology in the National Interest, Lexington, MA: MIT Lincoln Laboratory, 1995.

42 These were the eight satellites launched between 1965 and 1976 in the Lincoln Experimental Satellite (LES) series.

43 Seamans to Sarabhai, 4 November 1969, MIT/Lincoln Lab Archives.

44 Sarabhai to Wiesner, 6 January 1970, MIT/Lincoln Lab Archives.

45 Nims to Johnson, 30 July 1970, MIT/Lincoln Lab Archives. 
finished in March 1971, and produced a workable design for a television broadcasting satellite. ${ }^{46}$

INSAT, as proposed by the MIT study, was supposed to be launched in 1975 but the project was delayed by Sarabhai's untimely death in December 1971; the Bangladesh war of independence, which drove a wedge between the US and India; and bureaucratic inertia and infighting in the Indian government over the need for such a satellite. The result was that the government did not formally approve INSAT until November 1975, nearly five years after the MIT study. ${ }^{47}$ The first INSAT was finally launched in 1982 , by which time the original broadcasting satellite had evolved into a multipurpose applications satellite platform for television broadcasting, telephone and data communications, and remote sensing. Nevertheless, as Y.S. Rajan, one of the original MIT study members, recently noted, the MIT study was 'the most important satellite study done under Sarabhai' in terms of its 'long-term significance' ${ }^{48}$ Beyond establishing a baseline satellite design configuration that would become the standard for ISRO in the 1980s, the experience at MIT provided hands-on applied science and engineering experience to several Indians, including Kale and Rajan, who later headed important projects back in India.

If MIT played a critical role in both fostering and enabling the early direction of Indian space activities, largely by inviting and hosting Indians who guided many aspects of the work of INCOSPAR, and later ISRO, it also exposed those Indians to a rich and international network of scientific activity spread across many different disciplines, economic sectors and countries. MIT was an important training ground for global scientific elites, part of a loose network that also included other American institutions such as Caltech, Stanford and the University of Chicago, as well as Cambridge and Oxford in the UK. ${ }^{49}$ Surprisingly, one of the largest foreign contingents at MIT, much larger than the Indian community, especially in the first half of the twentieth century, came not from a European nation but from China. Already by 1915 there were forty-six Chinese students at MIT, the largest foreign student population, and by the time of the revolution in 1949 over three hundred Chinese students had received their higher education from MIT,

46 MIT-ISRO, INSAT Satellite Systems Study: Volume I (INSAT Summary Report, March 1, 1971), Volume II (INSAT Satellite Design Study, March 1, 1971), and Volume III (INSAT Program Cost Analysis, December 7, 1970), MIT/Lincoln Lab Archives.

47 For more on this tortured stage see Bella Mody, 'Contextual analysis of the adoption of a communications technology: the case of satellites in India', Telematics and Informatics (1987) 4, pp. 151158; Jai P. Singh and K. Narayan, 'Broadcasting-satellite service in India', IEEE Journal on Selected Areas in Communications (1985) 3, pp. 233-245; Raman Srinivasan, 'No free launch: designing the Indian satellite', in Andrew J. Butrica Jr (ed.), Beyond the Ionosphere: The Development of Satellite Communications, Washington, DC: NASA, 1997, pp. 215-226.

48 Interview with the author, Y.S. Rajan, Bangalore, 5 August 2011.

49 For critical histories of MIT see David Kaiser (ed.), Becoming MIT: Moments of Decision, Cambridge, MA: MIT Press, 2010; Stuart Leslie, The Cold War and American Science: The Military-Industrial-Academic Complex at MIT and Stanford, New York: Columbia University Press, 1993. For Western academic institutions embedded in international networks see Hans de Wit, Internationalization of Higher Education in the United States of America and Europe: A Historical, Comparative, and Conceptual Analysis, Westport, CT: Greenwood Press, 2002. For Stanford see Rebecca S. Lowen, Creating the Cold War University: The Transformation of Stanford, Berkeley: University of California Press, 1997. 
almost all of whom returned home. ${ }^{50}$ They constituted a small but important segment of roughly 22,000 Chinese who studied in the US over a period of a hundred years. The number in the US in 1949 amounted to roughly five thousand. ${ }^{51}$

McCarthyism and general anti-communist hysteria created adverse conditions for Chinese studying in the United States, and contributed to a brief period after 1949 when large numbers of Chinese returned home. Soon, by 1951, as Zuoyue Wang has shown, 'a gradual change in U.S. policy began to make it increasingly difficult for Chinese students and scientists to return to China'. ${ }^{52}$ Most of the five thousand stayed behind in the US, many of whom were active in the American aerospace industry, particularly in southern California. ${ }^{53}$ The ones who returned, about a thousand, were seeded in key positions in the Chinese scientific and military-industrial communities. Wang notes that between 1949 and 1956, of those who came back to China, 129 went to work in the elite Chinese Academy of Sciences. He adds, 'Both individually and as a group, it is difficult to overestimate the importance of those returned students and scientists to the Chinese nuclear weapons and space program'. ${ }^{4}$ Of the higher echelon of the Chinese Academy of Sciences, more than a quarter earned their graduate degrees in the United States, and of these MIT was by far the largest in terms of degrees granted (twenty-one PhDs). ${ }^{55}$ Three of the most important scientific and engineering heads of the nascent Chinese missile and space programmes were intimately connected with MIT. They included Liang Shoupan (1916-2009), who obtained his graduate degree at MIT in 1940, and was the leading rocket propulsion expert in the early missile programme. There was also Tu Shoue (1917-2012), who graduated from MIT in 1943, worked for a while at a Curtiss Aircraft factory in Buffalo, New York, and later, upon his return to China, was in charge of the most important missile project in the late 1950s, the effort to reverse-engineer and produce a domestic version of a Soviet ballistic missile. Undoubtedly, the most famous alumnus of MIT was, of course, Qian Xuesen (1911-2009), considered by many to be the 'father' of the Chinese missile and space programme.

Did the return of Chinese scientists and engineers contribute to the 'Americanization' of Chinese science, at least in the short term? Wang qualifies it as a 'partial Americanization', a kind of co-production of knowledge systems that accumulated practices, institutional

50 Sarah Yu, 'MIT's Chinese contingent,' Scope, at http://scopeweb.mit.edu/articles/mits-chinesecontingent, accessed 18 January 2016.

51 These numbers are debatable and there has been no systematic study of Chinese student populations. The New York Times quoted a figure of 22,000 Chinese students up to 1954. See 'Centennial for Chinese students', New York Times, 31 October 1954. See also Stacey Bieler, 'Patriots' or 'Traitors'? A History of AmericanEducated Chinese Students, Armonk: M.E. Sharpe, 2004; Ting Ni, 'Cultural journey: experiences of Chinese students of the 1930s and the 1940s', PhD dissertation, Indiana University, 1996; Y.S. Wang, Chinese Intellectuals and the West, 1872-1949, Chapel Hill: University of North Carolina Press, 1966.

52 Wang, op. cit. (10), p. 371.

53 Zuoyue Wang, 'Engineering a new space: Chinese American scientists and engineers in aerospace in Southern California', in Peter Westwick (ed.), Blue Sky Metropolis: A Century of Aerospace in Southern California, Berkeley: University of California Press, 2012, pp. 197-213.

54 Wang, op. cit. (10), p. 373.

55 Cong Cao, 'Research note: social origins of the Chinese scientific elite', China Quarterly (1999) 160, pp. 992-1018. 
modes and ideologies rooted in the United States, China, Europe, Japan and the Soviet Union, facilitating a transnational process of knowledge circulation. Much like the imported but locally shaped modernization theories in play in the Indian context, the returned diaspora of Chinese scientists appears to have preferred some token, if not substantive, institutional features of the American educational model. Wang describes Qian Xuesen's advocacy of the 'American model of innovative scientific education' - presumably the emphasis on experimentation in pedagogy - in place of existing Chinese arrangements. What is certain is that the US-returned diaspora had enormous clout once they returned. Wang notes that

the students and scientists were welcomed back in China with open arms, and many of the returnees took key positions in the Chinese research, development, and educational systems, especially in the defense sector. The cutting edge science and technology they brought back gave the Chinese leaders growing confidence that China could indeed launch its modernization drive. It may have also encouraged the Chinese leadership to pursue increasing independence from the Soviet Union. ${ }^{56}$

\section{Beijing}

Most, if not all, accounts of the birth of Chinese space and missile programmes follow a standard narrative that puts a 'father figure' at the centre, in this case Qian Xuesen, the charismatic United States-educated scientist who many now identify as the 'founder' of the Chinese missile and space programmes. Qian's story is well known but it bears repeating to highlight points of both similarity to and exception from those of other Chinese and Indian elites of his generation. Like most foreign-educated Chinese scientists of his cohort, Qian completed his graduate education in the United States, moving at first to MIT, where he earned a master's degree in 1936, and then to the California Institute of Technology. Having trained under mathematician Theodore von Kármán at Caltech, Qian co-founded, with von Kármán and Frank Malina, the Jet Propulsion Laboratory in Pasadena, California as a central site for advanced rocket propulsion research in the United States. ${ }^{57}$ His interests were wide, his accomplishments notable, and his ambitions at least in his chosen discipline of aeronautics - boundless. As his research gravitated towards long-range rocketry and space research, events outside his control impinged on his career path. Accused of being a communist at the height of McCarthyism in 1950, the FBI revoked his security clearance. When he decided to go back to China, he was forcibly put under house arrest, where he languished for a good five years. Disgruntled with the way the United States government had handled his case, he permanently returned to China in September 1955..$^{58}$

As soon as he returned to China, Qian proposed a plan to initiate the development of long-range missiles in China. In February 1956 he submitted a proposal to the Central

56 Wang, op. cit. (10), p. 373.

57 Clayton R. Koppes, JPL and the American Space Program: A History of the Jet Propulsion Laboratory, New Haven: Yale University Press, 1982.

58 Biographical details are from Iris Chang, Thread of the Silkworm, New York: Basic Books, 1995. 
Committee of the Communist Party to develop the national aerospace industry. ${ }^{59}$ The plan drew the attention of Party members at the top level, in particular Zhou Enlai, at the time the premier (head of the administrative State Council) and the chairman of the National Committee of the Chinese People's Political Consultative Conference, the most powerful advisory body to the Communist Party hierarchy. Through Zhou's intervention, the Chinese government formed, on 13 April 1956, the first institutional body to direct ballistic-missile development, the Aviation Industry Committee. This committee essentially a policy-making body - was headed by Marshal Nie Rongzhen, the powerful defence industrialist at the helm of both the Chinese atomic energy and missile programmes. ${ }^{60}$ Mao Zedong was kept appraised of early discussions about the ideal strategy to cultivate a missile programme, but emphasized in the early years, as he did with the atomic energy programme, that maximum use be made of Soviet assistance for the missile programme. ${ }^{61}$

Having proposed the development of rockets, the next step was to set up the infrastructure to manage and implement the project. In May 1956, Nie submitted to the Central Committee of the Communist Party 'An initial proposal to establish missile technology research in China' which laid out a possible structure for the effort. Based on Nie's suggestions, Zhou Enlai approved the idea and tasked Nie and Qian with establishing several institutions, including one to focus exclusively on missile research and development, ultimately known as the Fifth Academy of the Ministry of Defence. Fully operational by October 1956, the academy's offices were set up in a former military hospital west of Beijing under the tutelage of military veteran Zhong Fuxiang and Qian. ${ }^{62} \mathrm{At}$

59 Titled 'A Proposal to Establish a Defense Aviation Industry in China,' the proposal was submitted to the Central Committee on 17 February 1956. See Li Chenchzhi (Li Chengzhi), Razvitie kitaiskikh kosmicheskikh tekhnologii (The Development of Chinese Space Technology), St Petersburg, Nestor-Istoriia, 2013, p. 14. This is an abridged Russian-language version of the most substantive historical work published in China on the early history of the Chinese missile and space programmes: Chengzhi Li, Zhongguo hangtian jishu fazhan shi gao (A Draft History of Space Technology in China), 3 vols., Jinan: Shandong Education Press, 2006. For a review see Isis (2010) 101, pp. 677-678.

60 The decision to form the committee was taken on 14 March but it came into operation only on 13 April. Later, in October 1958, the committee was merged with the Fifth Bureau of the Ministry of Defense into the Commission of Science and Technology for National Defense (CSTND). In 1982, CSTND was expanded into the Commission of Science, Technology, and Industry for National Defense (COSTIND), which in 1998 was restructured as the General Armaments Department of the Ministry of Defense. In its various forms, COSTIND was China's principal governmental body in charge of the managing its missile and space programmes.

61 For English-language accounts of this early period see John Wilson Lewis and Xue Litai, China's Strategic Seapower: The Politics of Force Modernization in the Nuclear Age, Stanford, CA: Stanford University Press, 1994, pp. 130-133; Mark A. Stokes, 'The People's Liberation Army and China's space and missile development: lessons from the past and prospects for the future', in Laurie Burkitt, Andrew Scobell and Larry M. Wortzell (eds.), The Lessons of History: The Chinese People's Liberation Army at 75, Carlisle, PA: Strategic Studies Institute, 2003, pp. 195-201, 203-204; Yanping Chen, 'China's space activities, policy and organization, 1956-1986', PhD dissertation, George Washington University, 1999, pp. 61-81; Zhihua Shen and Yafeng Xia, 'Between aid and restriction: changing Soviet policies toward China's nuclear weapons program: 1954-1960', Nuclear Proliferation International History Project, Working Paper \#2, May 2012, at www.wilsoncenter.org/sites/default/files/soviet_policies_twrds_chinas_nuclear_weapons_prgm_1. pdf, accessed 4 January 2016.

62 The institutional framework for missile development in China was initially operated through two entities, the Fifth Bureau (to manage development), opened on 6 August 1956, and the Fifth Academy (to carry out 
least 150 young university graduates were recruited for work at the academy, but the key scientific luminaries, besides Qian, were the two MIT-trained experts Liang Shoupan and Tu Shoue, and a third scientist, Huang Weilu (1916-2011), a graduate (1947) of Imperial College London.

Creating a ballistic-missile programme from the ground up was a tall order for Chinese industry. Some, like Nie, would talk in language that eerily prefigured the rhetoric of Indian system-builders such as Homi Bhabha ten years later (and, like Bhabha, Nie also integrated the nuclear and space programmes under a single umbrella). In a letter Nie sent to the Central Committee of the Communist Party in October 1956, he wrote that China's policy in building a missile programme should encompass 'mainly self-reliance, acquiring foreign assistance as much as possible, and making use of technological achievements developed in capitalist countries' ${ }^{63}$ Unlike India, however, the entire project to develop indigenous rockets was wholly driven in China by military imperatives, and thus its place in the matrix of Chinese science and technology was defined not only by secrecy but also by sensitivities to Chinese foreign policy, the most important external relationship being with fellow socialist ally the Soviet Union.

The Soviet contribution to the development of the Chinese missile programme was significant but it is difficult to evaluate without an understanding of the overall scope of Soviet-Chinese rapprochement in the 1950s, which included economic, scientific and military dimensions. From the very inception of Communist rule in China in 1949, the two sides began discussions about mutually beneficial cooperation, focused particularly on science and industry. Besides common ideological foundations, China and the Soviet Union shared common security concerns, reinforcing ties in the light of a perception of general isolation in the international arena. Beginning in 1950, representatives signed a series of economic agreements designed specifically to help China industrialize on a massive scale through the transfer of designs of industrial equipment, shipment of manufacturing technologies, assignment of Soviet experts to Chinese industry, and training of Chinese experts, both domestically and in the Soviet Union. Sectors targeted included the industries of steel, petroleum, machine tools, heavy machinery, power plants, automobiles, tractors, locomotives, film, heavy artillery, tanks, jets and aeroplanes. ${ }^{64}$ As Zhang, Zhang and Yao note, 'China had not manufactured most of these

research and development), opened on 8 October 1956. The two merged into the single Fifth Academy, after an order issued on 1 March 1957. Later, in May 1958, a new Fifth Department was organized to supervise the Fifth Academy. This Fifth Department was merged into the larger CSTND in April 1959, thus bringing the missile programme under the control of CSTND. For details see Li Chenchzhi, op. cit. (61), p. 16; Lewis and Xue Litai, op. cit. (63), p. 256. In terms of their specific positions, Zhong and Qian were respectively director and deputy director at the Fifth Bureau, but Qian also served as director of the Fifth Academy until 1960, when he evidently voluntarily took the deputy director position in order to concentrate more on technical matters.

63 Chen, op. cit. (63), p. 73.

64 For general overviews see Thomas P. Bernstein and Hua-yu Li (eds.), China Learns from the Soviet Union, 1949-Present, Lanham, MD: Lexington Books, 2010; Odd Arne Westad (ed.), Brothers in Arms: The Rise and Fall of the Sino-Soviet Alliance, 1945-1963, Stanford, CA: Stanford University Press, 1998; T.G. Zazerskaia, Sovetskie spetsialisty i formirovanie voenno-promyshlennogo kompleksa kitaia, 1949- 
products; if it had, Chinese products were substandard. But now China sought to acquire the design of accessories and equipment that Chinese factories could manufacture'. ${ }^{65}$

Scientific aid constituted an important part of many of the agreements signed by the two parties, enabled by Mao's admonition in February 1953 that all Chinese learn from Soviet science and technology. ${ }^{66}$ In this context, the Chinese Academy of Sciences, although populated by a significant coterie of Western-educated elites, adopted practices considered normative in Soviet science and industry. ${ }^{67}$ These were invoked explicitly in official directives, such as that issued in October 1952, when the academy leadership approved its 'Decision ... on Strengthening the Learning and Introducing [of] Soviet Advanced Science'. ${ }^{68}$ By 1953, over 90 per cent of the staff of the academy could speak Russian, while nearly 75 per cent could read Russian. The orientation towards the Soviets happened in different registers in several economic and industrial branches. Institutionally, for example, the Chinese adopted many prevailing Soviet forms of personnel and organizational norms in the Chinese Academy of Sciences (the disengagement of the academy from pedagogy, for example), in industrial enterprises (having 'special committees' for extraordinary projects) and in R \& D organizations (having a 'first deputy chief' for managerial control of projects). ${ }^{69}$

Like science, military help was at the forefront of the Chinese-Soviet relationship from the very moment the Treaty of Friendship was signed by Stalin and Mao in February 1950. Initial Soviet assistance included the assignment of nearly four thousand Soviet 'advisers' from the navy and army in various Chinese installations, followed by the delivery of MiG-15 aircraft in March $1950 .{ }^{70}$ Such arms deliveries became more common through the decade, but a substantive change came in the late 1950s with an evolution to the question of weapons of strategic value, particularly atomic weapons and then missiles. Chinese leaders also emphasized, especially in internal deliberations, the urgency

1960 gody (Soviet Specialists and the Formation of China's Military-Industrial Complex, 1949-1960), St Petersburg: NIIKh SpbGU, 2000; E.S. Levina, 'Istoriia i problemy sovetsko-kitaiskogo sotrudnichestva v 1950-kh - nachale 1960-kh gg.: (po materialam rossiiskikh arkhivov)' (History and problems of SovietChinese cooperation in the 1950s-early 1960s: (based on materials from Russian archives)) in Rossiiskokitaiskie nauchnye sviazi: problemy stanovleniia $i$ razvitiia (Russian-Chinese Scientific Communications: Problems of Formation and Development), St Petersburg, 2005, pp. 92-116.

65 Baichun Zhang, Jiuchun Zhang and Fang Yao, 'Technology transfer from the Soviet Union to the People's Republic of China, 1949-1966', Comparative Technology Transfer and Society (2006) 4, pp. 105-171, 115.

66 Zhang, Zhang and Yao, op. cit. (67), p. 122.

67 For a history see Shuping Yao, 'Chinese intellectuals and science: a history of the Chinese Academy of Sciences (CAS)', Science in Context 3 (1989) 3, pp. 447-473.

68 Zhang, Zhang and Yao, op. cit. (67), p. 122.

69 A two-volume collection of primary documents published by the Federal Archive Agency in Russia details many of these adopted practices. See V.S. Miasnikov (ed.), Kitaiskaia noradnaia respublika $v$ 1950-e gody: sbornik dokumentov (The People's Republic of China in the 1950s: A Collection of Documents), 2 vols., Moscow: Pamiatniki istoricheskoi mysli, 2010. The first volume compiles the contemporaneous impressions of Soviet and Chinese actors involved in the decade-long exchange. The second compiles government documents from the Soviet side.

70 A.B. Shirikorad, Rossiia $i$ kitai: konfliktu $i$ sotrudnichestkvo (Russia and China: Conflict and Cooperation), Moscow: Veche, 2004, p. 323. 
of transitioning from simply purchasing weapons to cultivating the capability to indigenously produce them. Nuclear cooperation took on its own particular dynamic, and the sharing of Soviet atomic expertise was never linear and without enormous obstacles, political and otherwise. ${ }^{71}$

In parallel with their interest in nuclear weapons, the Chinese actively sought delivery systems for them, including missiles. Chinese leaders such as Zhou Enlai and Nie Rongzhen believed, and not without good reason, that a whole host of advanced technologies, such as computing, rocketry, aviation and nuclear power, should be considered parts of a whole. In this matrix, rocketry played a central role based on the belief that its synergistic connection to a variety of sectors would energize the building of infrastructure to support a wide range of military developments. Although Nie and Qian were committed to going it alone if necessary, they also consistently sought out Soviet help at each step. ${ }^{72}$ Counselled by the two on the need to set up a missile programme, on 17 August 1956 Vice Premier Li Fuchun sent an exploratory letter to Nikolai Bulganin, the chairman of the Soviet Council of Ministers, for assistance with the missile programme. ${ }^{73} \mathrm{Li}$ noted that the Chinese were prepared to send a delegation to Moscow to hammer out the stipulations of an aid package. The Soviets responded less than a month later with an offer to host fifty Chinese students in Soviet institutions to study rocketry design, to send Soviet experts to Chinese universities, to make available technical manuals and, most important, to send two models of the short-range R-1 missile to the Fifth Academy. ${ }^{74}$ The R-1, being practically obsolete in every way, was not exactly what the Chinese were seeking; the missile was essentially a Soviet version of the famous German A4 (or V-2) missile that the Peenemünde team had developed in Nazi Germany during the Second World War. The Soviets had briefly deployed the missile, with a range of about 270 kilometres, in the early 1950s, but almost all had been decommissioned. ${ }^{75}$ Although disappointed with the Soviet offer, the Chinese signed their first official agreement to receive assistance on 'special technology', which included a provision to deliver several of these old rockets, all paid for in currency by the Chinese. ${ }^{76}$ In the spring of 1957 , once the R-1 rockets arrived at the Fifth Academy, Qian approved a plan to have Chinese engineers completely disassemble them and study and produce drawings of every single part, and then reassemble the two missiles, a process that took over six months.

71 Liu Yangqiong and Liu Jifeng, 'Analysis of Soviet technology transfer in the development of China's nuclear weapons', Comparative Technology Transfer and Society (2009) 7, pp. 66-110; Viktor M. Gobarev, 'Soviet policy toward China: developing nuclear weapons: 1949-1969', Journal of Slavic Military Studies (1999) 4, pp. 1-53; Zhihua Shen and Yafeng Xia, op. cit. (63).

72 See Xiaobing Li, A History of the Modern Chinese Army, Lexington: University Press of Kentucky, p. 153.

73 Bulganin's position meant that he was the nominal head of the Soviet government. Li was also chairman of the State Planning Commission, the governmental body in charge of economic planning at the state level.

74 Li Chenchzhi, op. cit. (61), p. 37.

75 Asif A. Siddiqi, Challenge to Apollo: The Soviet Union and the Space Race, 1945-1974, Washington, DC: NASA, 2000, pp. 41, 49, 53, 56, 57, 58.

76 The terms of exchange of the accord (signed on 30 March 1957) are noted in Zhihua Shen and Yafeng Xia, op. cit. (63), pp. 18-19. 
If the Soviet stance on sharing highly sensitive missile technology was at first marred by institutional and cultural reticence, geopolitical posturing moved the two countries together for a brief period, as the Chinese provided key support to Nikita Khrushchev during the so-called anti-Party affair in the summer of 1957 when Khrushchev's power was under threat from opponents within the Communist Party. Very soon after, in July 1957, Nie met with the Soviet adviser in Beijing, V.A. Arkhipov, requesting more nuclear and missile technology. ${ }^{77}$ Khrushchev responded quickly and loosened the reins on Soviet military aid, resulting in a burst of new activity. Subsequently, Marshal Nie led a large delegation of Chinese diplomats, scientists and experts to Moscow, the result of which was a second agreement, signed on 15 October, wherein the Soviets offered to provide significantly more missile and aviation equipment, blueprints and advisers on loan to China. The high point of this agreement was the delivery, on 24 December 1957, of two Soviet R-2 missiles (and associated ground facilities, blueprints and testing equipment loaded in sixty railcars) to the Fifth Academy in Beijing. ${ }^{78}$

The R-2, although possessed of better performance than its predecessor (a range of six hundred kilometres), was also consigned to history by Soviet designers, for they had moved far ahead by that point to develop intercontinental missiles. Igor' Larionov, one of the Russians assigned to Beijing, recalls that the 'Chinese were unhappy with the R-2', but adds that the Chinese worked 'with special diligence, showing zeal and perseverance' in their goal: to reverse-engineer the Soviet rocket and build an exact Chinese copy. ${ }^{79}$ Echoing the exact same strategy that the Soviets used after the Second World War, Qian saw the industrial manufacture of an already proven product using local materials as a step in creating infrastructure absolutely necessary for more ambitious projects and, in his words, 'to avoid detours'. ${ }^{80}$ Appropriately, leading the 102-man Soviet team to Beijing was one Lieutenant-General Lev Mikhailovich Gaidukov, the very same officer who had organized the production of the Soviet copy of the original German V-2 rocket after the war. ${ }^{81}$ To facilitate all this activity, the Fifth Academy, with Soviet help, organized two subordinate teams to manage the missile programme: the 'First Branch', located in the south-western Beijing suburb of Yungang responsible for overall missile design and propulsion, and the other, the 'Second Branch', located off Yongding Road in western Beijing responsible for missile control systems. ${ }^{82}$ Both of these branches were conceived, designed and organized based on agreements with

77 Xiaobing Li, op. cit. (74), p. 153.

78 Li Chenchzhi, op. cit. (61), p. 37; Zhihua Shen and Yafeng Xia, op. cit. (63), pp. 24-25.

79 Vladimir Platonov, 'SSSR-Kitai: raketno-iadernoi roman' ('USSR-China: Rocket-Nuclear Novel'), Zerkalo nedeli, 14 November 2003, available at http:/gazeta.zn.ua/SOCIETY/sssr_kitay_raketnoyadernyy_roman.html, accessed 8 January 2016.

80 Zhihua Shen and Yafeng Xia, op. cit. (63), p. 25.

81 Asif A. Siddiqi, The Red Rockets' Glare: Spaceflight and the Soviet Imagination, 1857-1957, New York: Cambridge University Press, 2010.

82 The branches were technically created on 9 November 1957 but did not begin operating before 18 January 1958 when a discussion with Soviet advisers led to an operational plan of work that included four projects known as 8102, 8103, 8108 and 8109. See Li Chenchzhi, op. cit. (61), pp. $26,37$. 
the Soviet side, and in many ways replicated exactly the organization of research institutions in the Soviet defence industry. ${ }^{83}$

The scope of Soviet aid deepened with the arrival of a new team of Soviet experts - this time mostly civilian engineers - in Beijing in August 1958 to organize production runs of the R-2. Heading the Soviet team was Petr Ivanovich Meleshin, a deputy to the highly influential and legendary 'chief designer' of the Soviet missile and space programme, Sergei Korolev; Meleshin had served as the production manager for the R-2 back in the late 1940s and early 1950s and thus knew the rocket better than anyone. Accompanying Meleshin was Nikolai Sergeevich Shniakin, a highly respected and experienced expert in the manufacture of rocket engines in Soviet industry. ${ }^{84}$ Both Meleshin and Shniakin had worked, in the early 1950s, at the Soviet Union's first mass-production facility - Factory No 586 in the parlance of Stalinist bureaucracy to build ballistic missiles, located in the Ukrainian city of Dnepropetrovsk. Now, in Beijing, they worked closely with Qian to orchestrate the initial production of parts of a Chinese version of the R-2 at a factory in Beijing - Factory No 211 in Maoist nomenclature. More help came in January 1959 when four more R-2 rockets arrived in Beijing. ${ }^{85}$ Further deliveries of other missiles were planned for 1959 and $1960 .{ }^{86}$

The cooperative relationship between the two countries, especially at the highest levels, was always steeped in ambivalence and anxiety, shaped especially by deep social and political changes both in the Soviet Union (such as de-Stalinization) and in China (such as the Great Leap Forward). Any tensions were further exacerbated by differing approaches to the future of international socialism, Soviet gestures towards nuclear arms control and, most strikingly, the demands of secrecy that characterized the Soviet rocket programme. ${ }^{87}$ The latter was a particularly sensitive issue that ensured that communication between Soviet and Chinese counterparts on the ground was always marred by suspicion and incomplete sharing of information. Further complicating their relationship was a lack of communication between the upper managerial levels and the ground technical levels on both sides. Soviet engineers at the ground level such as Meleshin and Shniakin, for example, had little or no indication that the relationship at the top was souring very quickly by 1961 . It was much the same on the

83 'Ob okazanii tekhnicheskoi pomoshchi kitaiskoi narodnoi respublik $\mathrm{v}$ sozdanii nauchnoissledovatel'skikh institutov po raketnoi tekhnike' (On providing technical aid to the People's Republic of China in the creation of scientific-research institutes for rocket technology), Russian State Archive of the Economy (RGAE), Fond (Collection) 4372, Opis' (Inventory) 77, Delo (Folder) 335, listov (leaves) 129-131.

84 Others on the team included Andrei Zarubin, Igor' Larionov, Ivan Lyska, Evgenii Semenov, Ivan Kozlov, Viktor Borodin and Dmitrii Anvarov. For details see A.V. Ponomarev, '24 aprelia - 20 let so dnia puska pervoi kitaiskoi rakety-nositelia "velikii pokhod-1" so sputniom "kitai-1" (1970)' (24 April - 20 years from the launch of the Chinese 'Long March-1' carrier-rocket with the 'China-1' satellite (1970)), Iz istorii aviatsii i kosmonavtiki (1990) 64, pp. 30-33.

85 Chen, op. cit. (63), p. 70, p. 235.

86 'Pis'mo predsedatelia gosudarstvennogo komiteta soveta ministrov sssr po aviatsionnoi tekhnike P.V. Dement'eva v sovet ministrov sssr o postavkakh oborudovaniia v knr (December 11, 1959)' (Letter from the Chairman of the State Committee of the Council of Ministers for Aviation Technology P.V. Dement'ev to the USSR Council of Ministers on delivery of equipment to the PRC) in Miasnikov, op. cit. (71), vol. 2, pp. 464-465.

87 These factors are described briefly in Zhihua Shen and Yafeng Xia, op. cit. (63). 
other side; Yanping Chen notes that 'the [Chinese] missile developers did not know that political tensions between the Chinese and Soviet Communist parties had reached a critical juncture'. 88

Ultimately, of course, these fissures at the top opened up into a chasm, and by 1960 the Sino-Soviet split threw a deep pall over any and all plans for cooperation between the two countries. As the Sino-Soviet disagreements over a variety of issues reached a critical (and very public) juncture, the Soviet Union terminated almost all cooperative agreements, but especially those of a defence character. In early 1960, Soviet missile designers began to leave Beijing, with the last one leaving on 12 August. All further deliveries, including ones that had been promised in prior agreements, were postponed and finally cancelled. At a meeting at the Fifth Academy, held about two months after the Soviet departure, Marshal Nie Rongzhen stated the obvious, that the Chinese would have to go it alone, but he added, 'We have to do things by ourselves. We cannot depend on others. We place our hopes in you, our missile experts'. 89

The most immediate goal of the post-Soviet period was to produce a fully Chinese version of the Soviet R-2, a rocket which was given the unimaginative designation '1059'. The key individual who kept the project going was MIT-trained Liang Shoupan, the missile's 'chief designer'. ${ }^{90}$ Under Liang's direction and in the presence of both Qian and Marshal Nie, the Chinese launched their first long-range ballistic missile, the 1059, from a remote location in the Gobi Desert, on 5 November 1960. The rocket successfully flew 550 kilometres and reached its target. Two more successful tests on 6 and 16 December confirmed Chinese confidence in their institutions and practices, and in the training of ground personnel at the Fifth Academy. These launches are typically remembered in official Chinese histories as founding moments in the Chinese missile and space programme. Less remembered is a launch of one of the Soviet-made rockets (albeit with Chinese-supplied propellants), which was fired a month earlier, on 9 September, a training exercise to verify all the systems for an all-Chinese rocket. ${ }^{91}$ This rocket was manufactured not in Beijing, but much farther away, in a large industrial city in Soviet Ukraine, Dnepropetrovsk. It is here that our narrative, from Thumba, to Cambridge, Massachusetts to Beijing, intersects with another Indian story.

\section{Dnepropetrovsk}

Of all the 'closed cities' of the Soviet Union - those where a large number of defence factories were concentrated and population flows were tightly controlled - Dnepropetrovsk was the most idiosyncratic. Located on the banks of the Dnepr river and the fourth-

88 Chen, op. cit. (63), p. 71.

89 Chen, op. cit. (63), pp. 72-73. Chen gives the date of this meeting as 14 August, while Li points to 9 October. They may have been separate meetings. Li quotes Nie with the following: '[we need] to make a breakthrough from copying to independent design quickly to develop and build our own high-technology system of missile technology - it will be difficult, but this is the honorable task facing us'. See Li Chenchzhi, op. cit. (61), p. 40.

90 Liang was named 'chief designer' of the 1059 on 31 March 1959. See Li Chenchzhi, op. cit. (61), p. 41.

91 Xiaobing Li, op. cit. (74), p. 170. 
largest city in Ukraine, Dnepropetrovsk was home to some of the most highly classified Soviet organizations, deeply involved in the missile, nuclear and space industries. Yet, as Sergei Zhuk has shown in his wonderful biography of the city, Rock and Roll in the Rocket City, it was also a place of contradictions: even as the CIA listed the city as one of its most important intelligence targets, local youth readily embraced Western popular culture and certain forms of religiosity, including Christianity but also Hinduism (inspired by the Beatles), as a mode of resistance to Soviet structures of control. ${ }^{92}$

In this odd mix of influences was seeded the largest missile production factory in the world, the so-called Iuzhnyi (or Southern) Machine Building Factory, usually shortened to Iuzhmash. When Nikita Khrushchev spoke of Soviet missiles 'coming out of factories like sausages', he was referring to Iuzhmash. Co-located with the factory was a lesserknown organization, the Iuzhnoe Design Bureau, the developer of the most capable intercontinental ballistic missiles in the Soviet Cold War arsenal. The histories of Iuzhmash (the factory) and Iuzhnoye (the design bureau) date back to the $1950 \mathrm{~s} .{ }^{93} \mathrm{It}$ is a history that is, like those of many other Soviet military-industrial enterprises, closed and isolated from the world, but with one exception: its history intersects at key points with technoscientific networks in both China and India.

After the Second World War, the first products of Soviet missile development were the R-1 (the Soviet copy of the Nazi V-2) and the R-2 (the domestic and improved version of the German rocket). These were 'designed' by the famous Scientific Research Institute No 88 under the tutelage of Sergei Korolev, the 'founder' of the Soviet space programme. In demand of a large production facility to manufacture these rockets on a mass scale, Soviet industrial leaders, including Nikolai Bulganin, who would later orchestrate Soviet-Chinese military cooperation, identified a large automobile factory in Ukraine which had been set up during wartime. In May 1951, the factory was reconsigned to the Ministry of Armaments, then responsible for the ballistic-missile programme, and all future production of R-1 and R-2 missiles transferred there. ${ }^{94}$ Its code name was simply 'Factory No 586'. One of the first engineers on the scene at the factory, in the autumn of 1951, was Nikolai Shniakin, the engine specialist who would, in seven years, escort missiles manufactured on the factory floor at Dnepropetrovsk to Beijing's 'Factory No 211'.

Although the Ukrainian factory was originally set up as a production facility, some of the senior personnel at the factory decided that they wanted to design their own missiles instead of mass-producing ones for others. As a way of creating redundancy in the design

92 Sergei I. Zhuk, Rock and Roll in the Rocket City: The West, Identity, and Ideology in Soviet Dnepropetrovsk, 1960-1985, Baltimore: Johns Hopkins University Press, 2010.

93 Vladimir Gubarev, Iuzhnyi start, Moscow: Nekos, 1998; V. Pappo-Korystin, V. Platonov and V. Pashchenko, Dneprovskii raketno-kosmicheskii tsentr (Dneprovskii Rocket-Space Center), Dnepropetrovsk: PO IuMZ/KBIu, 1994; S.N. Koniukhov (ed.), Prizvany vremenem: rakety i kosmicheskie apparaty konstruktorskogo biuro 'Iuzhnoe' (Called by Time: Rocket and Space Vehicles of the 'Iuzhnoe' Design Bureau), Dnepropetrovsk: Art-Press, 2004.

94 Orders for mass production of the R-1 and R-2 missiles at Dnepropetrovsk were signed on 1 June and 30 November 1951 respectively. See Pappo-Korystin, Platonov and Pashchenko, op. cit. (95). 
of long-range missiles, Bulganin sanctioned the creation of a new design group at the factory in April 1954 and appointed a talented engineer (and good communist) named Mikhail Iangel' to head it. ${ }^{95}$ This proved to be a fortuitous selection, for under Iangel's leadership, this small design group became, within a decade, the most important developer of ICBMs. By the mid-1960s, Iangel's stature had him hobnobbing with the likes of Nikita Khrushchev and Leonid Brezhnev, and brought an enormous building boom into Dnepropetrovsk. The city became identified with missiles, as engineers, technicians and managers flocked there to work.

Iangel's ambitions eventually led him to the next sector beyond missiles - space. In the early 1960s, his Iuzhnoe Design Bureau began an aggressive programme of developing small and medium-sized satellites for the military and scientific communities while also fielding a reliable family of satellite launch vehicles. These were not the achievements that brought public recognition to the Soviet space programme - Iangel's rockets did not launch cosmonauts or grace the cover of magazines - but he developed Iuzhnoe's reputation as a highly dependable organization with an enviable professional work culture. For this reason, when Soviet Party functionaries signed agreements to implement joint space science programmes with 'friendly socialist countries' - known under the moniker 'Interkosmos', Iuzhnoe was the ideal choice. ${ }^{96}$ So when Vikram Sarabhai dispatched a letter to his Soviet colleagues in July 1971 about the possibility of drawing from Soviet expertise to build and launch an Indian satellite, Soviet planners immediately suggested Iuzhnoe as the ideal partner. ${ }^{97}$ It undoubtedly helped that Iangel' himself was friends with K.P.S. Menon, the former Indian ambassador to the Soviet Union, and counted himself a bit of an Indophile, being fascinated with the Russian mystic painter Nicholas Roerich (Nikolai Konstantinovich Rerikh), who had travelled through South Asia numerous times in the 1920s and 1930s and had met both Nehru and his daughter Indira Gandhi. Roerich's son, Svetoslav (Sviatoslav), also a well-known painter, had settled on the outskirts of Bangalore - home of the Indian space programme - for nearly fifty years, having moved there soon after the Second World War. When Soviet engineers visited Bangalore to discuss the making of an Indian satellite, the younger Roerich played host to his countrymen, some of whom were fascinated by the Roerich family's idiosyncratic and orientalist sensibilities about 'eastern mysticism'. ${ }^{98}$

From Sarabhai's perspective, the turn to Soviet science did not appear out of the blue. During his stint as head of INCOSPAR and later as head of the newly formed Indian Space

95 S.N. Koniukhov (ed.), Rakety i kosmicheskie apparaty konstruktorskogo biuro 'Iuzhnoe' (Rocket and Space Vehicles of the 'Iuzhnoye’ Design Bureau), Dnepropetrovsk: GKB 'Iuzhnoe’ im. M.K. Iangelia, 2001, pp. 8-10.

96 The Interkosmos project resulted in the launch of more than two dozen satellites into orbit carrying experiments from all the Soviet bloc nations, including the German Democratic Republic, Czechoslovakia, Poland, Hungary, Bulgaria and Romania. In the late 1970s the programme was extended to include launches of guest cosmonauts into space from these and other socialist nations.

97 Sarabhai to the Soviet embassy in Delhi, 26 July 1971, Archive of the Russian Academy of Sciences (ARAN), Fond 1679, Opis' 1, Delo 111, list 1.

98 Vladimir Gubarev, Aryabhata: The Space Temple, New Delhi: Sterling Publishers, 1976, pp. 34-37. For Roerich in general see Alexander Andreyev, The Myth of the Masters Revived: The Occult Lives of Nikolai and Elena Roerich, Leiden: Brill, 2014. 
Research Organisation (ISRO) he had displayed a noticeable openness to scientific and technical collaboration with any willing participant, especially those linked to international scientific networks. Besides key agreements with the Americans and the French, in 1963 Sarabhai had signed an agreement with the so-called USSR Hydrometeorological Service for the latter to provide equipment - a helicopter, a computer and a rocket vibration table - for use at Thumba. These cursory contacts with the Soviets had expanded into a major bilateral agreement between the two countries, signed in May 1970, to host launches of rather simple Soviet weather rockets from Thumba in 1970 and $1971 .{ }^{99} \mathrm{~A}$ large set of Soviet equipment arrived at Thumba by ship to support these launches, introducing Indian engineers to both Soviet engineering and Soviet engineers. By this time, Sarabhai had tabled an incredibly ambitious ten-year plan of research for ISRO that included the development of an indigenous satellite, a launch vehicle for it, a launch site on the eastern coast north of Madras, and more advanced satellites such as INSAT.100 Realizing that all of this would require modest steps in the early years, he conceived of an idea to launch a small satellite into orbit using a Soviet rocket as a first step. ${ }^{101}$

Fortuitously, the political climate at the time also favoured a closer relationship between India and the Soviet Union. While political (and, as a result, technical) cooperation with the United States had been unusually open and forthcoming through much of the 1960s, the 1971 Bangladesh war of independence, where the United States threw its full support behind (West) Pakistan in their brutal attack on East Pakistan, introduced a marked coolness in relations between the two countries. ${ }^{102}$ Sarabhai's 'feelers' to Soviet science thus emerged as an understandable, albeit opportunistic, response to de-prioritizing cooperation with American institutions, and built upon a major friendship agreement signed between the Soviet Union and India in August 1971. ${ }^{103}$ This set the stage for a series of intensive discussions in Moscow (in August 1971) and Bangalore (in February 1972) on what kind of cooperative work on space science was possible. Sarabhai's untimely death in December 1971 appears not to have impeded work on

99 'Spravka o provodimykh rabotakh v oblasti izucheniia kosmicheskogo prostranstva po programmam sotrudnichestva s sotsialisticheskim stranam, frantsiei, indie i SShA' (Document on carrying out work in the area of the study of cosmic space within the program of cooperation with socialist nations, France, India, and the USA), July 1971, RGAE, Fond 8061, Opis' 9, Delo 2446, listov 15-24.

100 For the famous space plan of 1970 see Atomic Energy Commission, op. cit. (19).

101 Sarabhai originally proposed having the Soviets bring one of their satellite launch rockets to India to carry out the launch from Indian soil but the Soviets firmly rebuffed this idea (on grounds of secrecy) and proposed a less objectionable option, to bring the Indian satellite to the Soviet Union for launch. See V. Sarabhai to M.V. Keldysh, 7 August 1971, ARAN, Fond 1678, Opis' 1, Delo 111, listov 2-3.

102 Gary J. Bass, The Blood Telegram: Nixon, Kissinger, and a Forgotten Genocide, New York: Alfred A. Knopf, 2013.

103 For Indian-Soviet relations during the Cold War see Vojtech Mastny, 'The Soviet Union's partnership with India', Journal of Cold War Studies (2010) 12, pp. 50-90; A.A. Iosifov, 'Nachalo formirovanniia partnerskikh otnoshenii mezhdu Sovetskim Soiuzom i Indei v nachale 70-kh godov veka' (The beginning of forming partner relations between the Soviet Union and India in the early 1970s), Izvestiia rossiiskogo gosudarstvennogo pedagogicheskogo universiteta im. A.I. Gertsena (2009) 118, pp. 40-42; Santosh Mehrotra, India and the Soviet Union: Trade and Technology Transfer, Cambridge: Cambridge University Press, 1990; David C. Engerman, 'Learning from the east: Soviet experts and India in the era of competitive coexistence', Comparative Studies of South Asia, Africa and the Middle East (2013) 33, pp. 227-238. 
an agreement between the two sides. Signed into law on 10 May 1972, the arrangement invited the Soviet Academy of Sciences to provide advisory and technical assistance to India in producing a satellite as well as a launching rocket free of charge. Sarabhai's successor, Satish Dhawan, strongly supported the project, which was presented to the Indians as being implemented by the 'Soviet Academy of Sciences'. This fiction was propagated to maintain the secret status of the organization tapped to help the Indians build the satellite, the Iuzhnoe factory (and its associated design bureau) in Dnepropetrovsk. In fact, so secretive were the Soviets that Iuzhnoe's chief designer, Viacheslav Kovtunenko, who served as the Soviet 'director' of the joint project, was identified simply as a professor at Dnepropetrovsk University instead of as one of the leading designers of Soviet nuclear-tipped missiles. ${ }^{104}$

Between 1972 and 1975, the Dnepropetrovsk team provided substantive assistance to ISRO in building the satellite. Kovtunenko's team contributed to choosing the basic design of the satellite, carried out the thermal calculations, and estimated the dynamic characteristics of the object. The Soviet organization also provided a gas jet system for spin-stabilizing the satellite, solar and chemical batteries, the onboard data recorder, thermal protection systems, and some other equipment. ${ }^{105}$ Most critically, Iuzhnoe provided the actual booster rocket that would launch the satellite into orbit, which in the open press was simply called the 'Kosmos' booster, but was, in fact, an upgraded version of a strategic medium-range missile (the R-14) that Dnepropetrovsk developed in the late 1950s at the same time that missiles manufactured in the same factory were readied for delivery to China. This rocket successfully launched the Indian Scientific Satellite into orbit around the Earth in April 1975 from a remote launch site near the Aral Sea, just a few months delayed from its original slated deadline of late 1974 . Indian delegates were invited to the launch but were restricted from seeing much of the launch site, which was part of a military missile test range. This, the very first Indian satellite ever launched into space, was christened Aryabhata by Prime Minister Indira Gandhi, in reference to the Indian mathematician who lived in the fifth and sixth centuries. ${ }^{106}$ Although the three scientific experiments on board the satellite built by Indian scientists from Sarabhai's PRL and Bhabha's TIFR - failed after five days in orbit, this was not an inconsiderable achievement for India and, as numerous memoirs attest, a transformative learning experience for ISRO engineers. ${ }^{107}$ Three days after the launch of Aryabhata, Soviet and Indian representatives, some of whom had worked at Thumba in the 1960s, signed a new agreement to launch a second satellite. Once again, Iuzhnoe provided support for the second satellite, and later for a third

104 For the 'open' document see 'Spisok sovetskoi delegatsii' (List of Soviet delegations), RGAE, Fond 1678, Opis' 1, Delo 230, list 80. The actual titles of the Soviet participants are listed in a secret document withheld from the Indians. See RGAE, Fond 1678, Opis' 1, Delo 232, list 11.

105 U.R. Rao to B.N. Petrov, 15 January 1973, RGAE, Fond 1678, Opis' 1, Delo 232, list 6.

106 Soon after, Soviet and Indian authorities published several books on Aryabhata and Soviet-Indian space cooperation in general. See Gubarev, op. cit. (100); U.R. Rao and K. Kasturirangam, The Aryabhata Project, Bangalore: Indian Academy of Sciences, 1978.

107 S. Dhawan, 'A glimpse of the Indian space programme', Proceedings of the Indian Academy of Sciences (1978) 1C, pp. 1-26. 
one, launched in 1979 and 1981, under the names Bhaskara-1 and Bhaskara-2 respectively. By this time, Indian space infrastructure had coalesced around Thumba, Bangalore, Ahmedabad, Sriharikota and many other locales, ready for the big push that came in the following two decades.

\section{Conclusions}

I have charted here a narrative of a kind of Cold War science, a narrative not of one place, nor of one time. It moves across different locations, often taking its actors with it, often picking up new ones. It disrupts the idealized chronology we expect of the production of knowledge. It highlights the 'embeddedness' of actors and sites in a global network, and it eschews the framework of the 'national programme' in favour of actions that cross boundaries that were defined by geography, claimed by national imperative, and regulated by international relations. The result is a global history without a reflexive standard (for example, 'the American space programme') against which the narratives of 'the other' are measured; as a result, there are no 'great divergences' (in the Needhamian sense) but rather processes operating at both the global and local levels mapped onto each other that reveal the sinews of contact between the two, rendering legible a new way to look at an old story - spaceflight activities during the Cold War. ${ }^{108}$

As I have noted in the introduction, historians of science and technology have engaged for quite some time now with questions of the 'global' in their work, parsing out the possible differences and limitations of such terms as the global, the local, the comparative and the national. ${ }^{109}$ We have debated particularly the problematic of circulation, undergirded by an interest in multiple mobilities - of the human, the material and the epistemic through space and through time. We have also been reminded that 'mobility should not be stressed to the extent that immobility, disjuncture, and the workings of the local are forgotten'. ${ }^{110}$ The heavy expectation of an accumulated body of theoretical meditation - concerned with all of these ideas - has, however, largely overshadowed empirical studies of the global history of science. The connections revealed in this empirical study on burgeoning Indian and Chinese work on rocketry and satellites embody an admittedly particular exemplar of a possible global history of science during the Cold War. It draws from the theoretical insights offered by others, but it is grounded in real-world examples, illustrating particularly the importance of 'the site' as an analytical heuristic for revealing

108 Although the phrase 'great divergence' has a more recent provenance (usually attributed to Samuel Huntington), the so-called counterfactual 'Needham question' had relevance for historians of science partly to explicate why 'modern science' emerged in Europe but not simultaneously in China. For a succinct summary of Needham's intervention into the debate on the emergence of modern science see Robert Finlay, 'China, the West, and world history in Joseph Needham's Science and Civilisation in China', Journal of World History (2000) 11, pp. 265-303.

109 For a useful summary see Francesca Bray, 'Only connect: comparative, national, and global history as frameworks for the history of science and technology in Asia', East Asian Science, Technology and Society: An International Journal (2012) 6, pp. 233-241.

110 Sujit Sivasundaram, 'Sciences and the global: on methods, questions and theory', Isis (2010) 101, pp. $146-158,158$. 
processes, movements and connections illegible within either nation-centred histories or comparative studies.

The sites I have selected - Thumba, Cambridge, Beijing and Dnepropetrovsk - reveal a history of Cold War science in motion. In seeking to produce an 'Indian' space programme, scientific elites such as Vikram Sarabhai leveraged their connections to a global network of science to create advanced infrastructure in the fishing village of Thumba in south India. The principal factor here was a general US policy towards cooperation with India, enabled to a large degree by MIT officials who argued in its favour. MIT was also a training ground for numerous key institutional actors in the Indian space project, many of whom received their higher education there, and one, Sarabhai, who had a permanent appointment as a visiting scholar. Using his connections to MIT, Sarabhai orchestrated the first major Indian satellite study at MIT, of a project known as INSAT, designed to be the first Indian satellite dedicated to national economic development. MIT was also, of course, the most important educational institution for a large number of Chinese scholars in the 1930s and 1940s, many of whom returned to Beijing to found the Chinese missile programme after the Communist Revolution. Many of these Chinese returnees (like their counterparts who remained in the US) were brilliant and resourceful, and enjoyed long careers in the world of aerospace. In line with Mao's efforts to set up domestic weapons programmes, China drew from this collective expertise to initiate a rocket programme. Soviet help, in both people and matériel, was indispensable for setting up initial production runs of Chinese rockets in Beijing in the late 1950s, enabled by massive Sino-Soviet collaboration in economic and military affairs that was somewhat abruptly shut down in the early 1960s because of the Sino-Soviet split. Many of the Soviet engineers and rockets in Beijing came from the Ukrainian industrial city of Dnepropetrovsk, where one could find the largest missile factory in the world, the producer of the Soviet Union's most powerful intercontinental ballistic missiles during the Cold War, all aimed at the United States. Dnepropetrovsk would also figure as a significant site for the early Indian space programme. In the early 1970s, when India and the Soviet Union initiated an agreement that called for the launch of an Indian satellite by a Soviet rocket, the same factory in Dnepropetrovsk that had worked with the Chinese was tapped to provide, now fifteen years later, support to the new Aryabhata satellite project. The satellite was designed and built jointly by Indians and Soviets, the former including many of the same engineers who had worked at Thumba a decade before, with American rockets sent to Kerala to establish an Indian space programme.

We see here that the narrative of India and China's efforts to create rockets and satellites to explore space cannot be contained in a single site or time. They were sprawling projects redolent of messy and unexpected phenomena that frequently clashed with claims framed around the 'national'. There is a resistance here, to clean narratives of the local or the global. The 'story' also represents a powerful empirical corrective to our received wisdom about the history of Cold War science as one neatly defined by bifurcated and bipolar considerations, static and well-defined. Instead, what we are left with is a set of key moments in the Cold War, found in several different sites, and embedded in a global network of science in motion, all linked by the common goals of building powerful rockets to explore space. 